\title{
The Potential of Acetylfuran and Furfural from Tamarindus indica as Lipoxygenase Inhibitor: In Silico Study
}

Apriani Herni Rophi ${ }^{1 *}$, Yohanes Bare ${ }^{2}$, Dewi Ratih Tirto Sari ${ }^{3}$

${ }^{1}$ Biology Education Study Program, Faculty of Teaching and Training Education, Cendrawasih University, Jayapura, Indonesia

${ }^{2}$ Biology Education Study Program, Faculty of Teaching and Training Education, Nusa Nipa University, Sikka, East Nusa Tenggara, Indonesia

${ }^{3}$ Department of Biology, Faculty of Mathematics and Natural Science, Brawijaya University, Malang, Indonesia

*Corresponding author: aprianihernirophi@gmail.com

Submitted: 6 September 2020

Accepted: 15 November 2020

Published: 29 Agustus 2021

\begin{abstract}
Background: Tamarindus indica is a type of plant sub-family Caesalpinioideae, which is predicted to have antiinflammatory properties. When inflammation occurs, arachidonic acid will undergo metabolism, the LOX pathway will release 5-lipoxygenase (5-LOX). Objective: This study aimed to analyze the potential of acetylfuran and furfural compounds on LOX action. Methods: The compound Acetylfuran (CID 14505), Furfural (CID 7362) were downloaded from the PubChem database. The 5-LOX protein was obtained from PDB (6N2W), preparation by removing ligands and molecules that bind to Discovery Studio V19.1.0.18287. Compound and protein interactions have interacted with the Vina autodock software integrated into the PyRX software and analyzed by Discovery Studio V19.1.0.18287. Results: The results showed that the content of Acetylfuran and Furfural compounds in Tamarindus indica is predicted to have the potential as an inhibitor of the LOX gene on different amino acid residues, namely 3 amino acid residues and 4 amino acid residues, respectively and produce binding energy. In addition, van der Waals forces, hydrogen and hydrophobic bonds were found, giving the strength of the bonds formed. Conclusion: Bioactive acetylfuran and furfural have the potential as a drug to curve inflammation in the human body.
\end{abstract}

Keywords: amino acid, anti-inflamatory, inflammation, lox, Tamarindus indica

\begin{abstract}
Abstrak
Pendahuluan: Tamarindus indica merupakan jenis tumbuhan sub-famili Caesalpinioideae diprediksi memiliki sifat anti inflamasi. Saat terjadi inflamasi, asam arakidonat akan mengalami metabolisme, jalur LOX akan melepaskan 5-lipoxygenase (5-LOX). Tujuan: Penelitian ini bertujuan untuk menganalisis potensi senyawa asetilfuran dan furfural terhadap LOX. Metode: Senyawa Acetylfuran (CID 14505), Furfural (CID 7362) diunduh dari database PubChem. Protein 5-LOX diperoleh dari PDB (6N2W), preparasi dengan menghilangkan ligan dan molekul yang mengikat Discovery Studio V19.1.0.18287. Interaksi senyawa dan protein berinteraksi dengan perangkat lunak autodock Vina yang terintegrasi dalam perangkat lunak PyRX dan dianalisis oleh Discovery Studio V19.1.0.18287. Hasil: Hasil penelitian menunjukkan bahwa kandungan senyawa Acetylfuran dan Furfural yang terkandung dalam Tamarindus indica diperkirakan berpotensi sebagai penghambat gen LOX dengan melakukan pengahambatan pada residu asam amino yang berbeda, yaitu masing-masing 3 residu asam amino dan 4 residu asam amino dan menghasilkan ikatan energi. Selain itu, gaya van der Waals, ikatan hidrogen dan hidropobik ditemukan yang memberi kekuatan ikatan yang terbentuk. Kesimpulan: Bioaktif asetilfuran dan furfural berpotensi sebagai obat untuk mengatasi peradangan pada tubuh manusia.
\end{abstract}

Kata kunci: antiinflamasi, asam amino, inflamasi, lox, Tamarindus indica 


\section{INTRODUCTION}

Tamarindus indica is a type of sub-family Caesalpinioideae plant belonging to the Fabaceae family (Adeola et al., 2010; Bhadoriya et al., 2011). The essential component obtained from Tamarindus indica $\mathrm{L}$ is part of the plant used in the pharmaceutical, food, chemical, and textile industries (Borquaye et al., 2020). The people used tamarin as a pharmaceutical therapy because of the polyphenol content. The bioactive compounds are proanthocyanidin (apigenin, catechin, procyanidin B2, epicatechin, procyanidin dimer, procyanidin trimer), taxifolin, eriodictyol, and naringenin (Adeola et al., 2010). Rossini's study in Putri (2017) discovered an analgesic effect in mice induced by Tamarindus' oral ethanol extract. Because Tamarindus indica is thought to have anti-inflammatory properties, this study provides information on reduced oedema in the legs of experimental animals.(Bhadoriya, 2012; Komakech et al., 2019).

Inflammation is one sign in the human body because of the immune system from the infection or injury (Abdulkhaleq et al., 2018). When inflammation occurs, there are differences in protein expression, where the amount of protein expressed is less when compared to healthy conditions (Bare et al., 2018). The inflammatory response is the activation of signalling pathways that regulate levels of inflammatory mediators in tissue cells (Bare et al., 2019; Chen et al., 2018). During inflammation, there is a process of releasing arachidonic acid, which is an inflammatory mediator, which undergoes metabolism through different pathways, namely cyclooxygenase (COX) (Sari et al., 2019) and the lipoxygenase (LOX) pathway. The LOX pathway will release 5-lipoxygenase (5-LOX), 12lipoxygenase (12-LOX), and 15-lipoxygenase (15LOX). The products of the COX pathway are prostaglandins (acute inflammatory mediators) and thromboxane, while those from the LOX pathway are leukotrienes and hydroperoxy fatty acids (Andriyono, 2019; Mueller et al., 2010). In decreasing inflammation in the body, it is necessary to control genes that increase inflammation, one of which is LOX.

Recent studies have shown the potential for LOX as a target for inflammatory therapy (Al-u'datt u'datt et al.,
2019). Previous research has explained that the LOX group is used as a good anticancer target, but there has been no further study on this (Putri, 2017). Therefore, clinical trials in cancer patients are initiated with the LOXL2 monoclonal antibody, and several LOX/LOXL2 drug development programs are underway, approaching clinical trials in patients (Mayorca-Guiliani \& Erler, 2013). Study of the role of Tamarindus indica in various chemical mediators, various cytokines and various chemical mediators that play a role in increasing the inflammatory process (Putri, 2017. This study aimed to analyze the potential of acetylfuran and furfural compounds on LOX action.

The introduction contains the background and objectives of the study. In addition, it can also include research reviews that have been done before by other researchers that are relevant to current research.

\section{MATERIALS AND METHODS}

\section{Materials}

The compounds Acetylfuran (CID 14505), Furfural (CID 7362) were downloaded from the PubChem database. The 5-LOX protein was downloaded from PDB (6N2W) and prepared by removing ligands and molecules that bind to Discovery Studio V19.1.0.18287.

\section{Method}

The compounds and proteins were interacted with the Vina autodock software integrated into the PyRX software and analyzed using Discovery Studio 9.1.0.18287 (Tiring et al., 2019).

\section{RESULTS AND DISCUSSION}

Lipoxygenase (LOX) is an enzyme that oxidizes arachidonic acid to produce leukotriene (LTs), which indicates inflammation in cells. We found several amino acids that were formed between acetylfuranlipoxygenase interactions. They are Gln549, Thr366, Thr371, Val553, Val243, Arg370, Ile365, Leu244, and Ser447 (Figure 1). The ligand and proteins are formed in the form of van der Waals forces (Gln549, Thr371, Val553, Ile365, Leu244, Ser447), Carbon Hydrogen Bond in the amino acid residue (Thr366) and Pi-Alkyl (Val243 and Arg370) with energy binding around $6,7 \mathrm{Kcal} / \mathrm{mol}$ (Table 1$)$. 


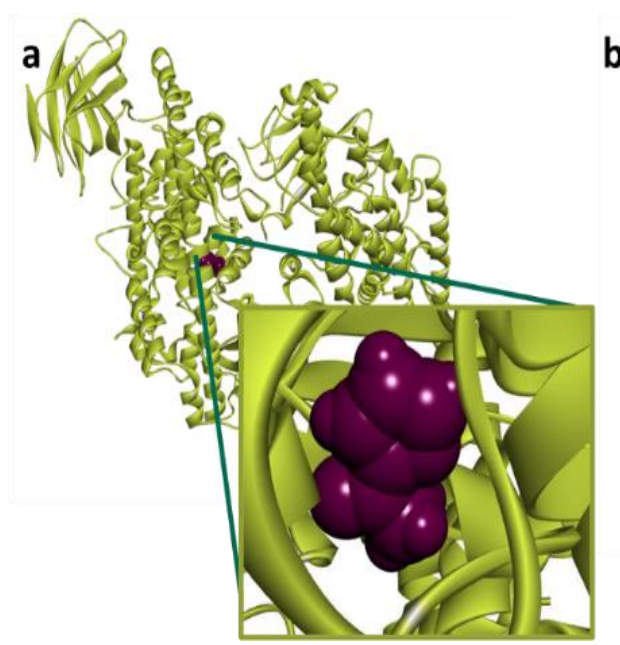

b

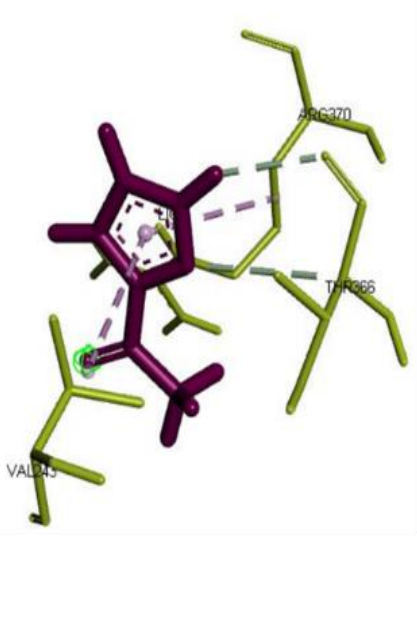

C

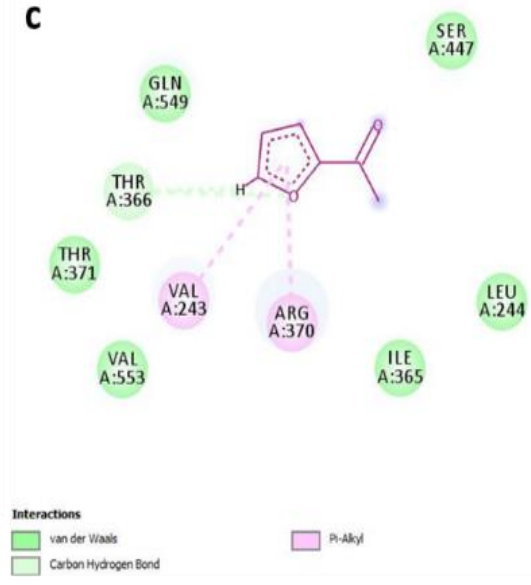

Figure 1. Interaction lipoxygenase-acetylfuran. a. structure of interaction between lipoxygenase-acetylfuran $b$. interaction lipoxygenase-acetylfuran 3D structure. c. interaction lipoxygenase-acetylfuran 2D structure

Table 1. Interaction between bioactive compounds of Tamarindus indica $\mathrm{L}$ and lipoxygenase

\begin{tabular}{|c|c|c|c|c|c|c|c|}
\hline Interaction & $\begin{array}{c}\text { Energy } \\
\text { (Kcal/mol) }\end{array}$ & Name & $\begin{array}{l}\text { Distan } \\
\text { ce(A) }\end{array}$ & Type & Type Bond & $\begin{array}{l}\text { atom } \\
\text { Donor }\end{array}$ & $\begin{array}{c}\text { Atom } \\
\text { Acceptor }\end{array}$ \\
\hline \multirow{4}{*}{$\begin{array}{l}\text { Lipoxygenase } \\
\text {-Acetylfuran }\end{array}$} & \multirow{4}{*}{$-6,7$} & $\begin{array}{l}\text { A:THR366: } \\
\text { CA - } \\
\text { :LIG1:O }\end{array}$ & 3,768 & $\begin{array}{l}\text { Hydrogen } \\
\text { Bond }\end{array}$ & $\begin{array}{c}\text { Carbon } \\
\text { Hydrogen Bond }\end{array}$ & H-Donor & H-Acceptor \\
\hline & & $\begin{array}{l}\text { :LIG1:H - } \\
\text { A:THR366: } \\
\text { O }\end{array}$ & 2,5265 & $\begin{array}{l}\text { Hydrogen } \\
\text { Bond }\end{array}$ & $\begin{array}{c}\text { Carbon } \\
\text { Hydrogen Bond }\end{array}$ & H-Donor & H-Acceptor \\
\hline & & $\begin{array}{l}\text { :LIG1 - } \\
\text { A:VAL243 }\end{array}$ & 4,5012 & Hydrophobic & Pi-Alkyl & $\begin{array}{c}\text { Pi- } \\
\text { Orbitals } \\
\end{array}$ & Alkyl \\
\hline & & $\begin{array}{l}\text { :LIG1 - } \\
\text { A:ARG370 }\end{array}$ & 4,0319 & Hydrophobic & Pi-Alkyl & $\begin{array}{c}\text { Pi- } \\
\text { Orbitals }\end{array}$ & Alkyl \\
\hline \multirow{5}{*}{$\begin{array}{l}\text { Lipoxygenase } \\
\text {-Furfural }\end{array}$} & \multirow{5}{*}{$-6,5$} & $\begin{array}{l}\text { :LIG1:H - } \\
\text { A:THR366: } \\
\text { O }\end{array}$ & 2,5535 & $\begin{array}{l}\text { Hydrogen } \\
\text { Bond }\end{array}$ & $\begin{array}{c}\text { Carbon } \\
\text { Hydrogen Bond }\end{array}$ & H-Donor & H-Acceptor \\
\hline & & $\begin{array}{l}\text { A:ARG370: } \\
\text { NH2 - :LIG1 }\end{array}$ & 4,5703 & Electrostatic & Pi-Cation & Positive & Pi-Orbitals \\
\hline & & $\begin{array}{l}\text { A:VAL243: } \\
\text { CG2 - :LIG1 }\end{array}$ & 3,6773 & Hydrophobic & Pi-Sigma & $\mathrm{C}-\mathrm{H}$ & Pi-Orbitals \\
\hline & & $\begin{array}{l}\text { :LIG1 - } \\
\text { A:ARG370 }\end{array}$ & 4,7349 & Hydrophobic & Pi-Alkyl & $\begin{array}{c}\text { Pi- } \\
\text { Orbitals }\end{array}$ & Alkyl \\
\hline & & $\begin{array}{l}\text { A:GLN549: } \\
\text { HE21 - } \\
\text { :LIG1:O }\end{array}$ & 1,6623 & Unfavorable & $\begin{array}{c}\text { Unfavorable } \\
\text { Bump; } \\
\text { Conventional } \\
\text { Hydrogen Bond }\end{array}$ & $\begin{array}{l}\text { Steric; } \\
\text { H-Donor }\end{array}$ & $\begin{array}{c}\text { Steric; } \\
\text { H-Acceptor }\end{array}$ \\
\hline
\end{tabular}

The interactions that occur between the compounds contained in Tamarindus indica have the potential as inhibitors of LOX. Research by Bare et al. (2019) reported the role of quinic acid on amino acid residues (Glu140, Asn144, Ser143, and Trp139) and B domain proteins (Glu236, Thr237, Lys333, Gln241, Gln330, Phe329, and Leu238) in the COX-2 gene. When compared with the studies in this study, it was found that there were very significant differences in the interacting amino acid residues. Each chemical component has a different interaction with the amino acid residue of LOX, which is found in Gln549, which is very specific only in the Lipoxygenase-Furfural interaction. The two bioactive equations that bind Lipoxygenase to the amino acid residue of Thr366 is hydrogen bonds, Val243 are hydrophobic bonds, and Arg370 are Pi-Alkyl and PiCation, respectively. The role of acetylfuran and furfural contained in Tamarindus indica is predicted at the molecular level. Tamarindus indica has a role in biomolecular vascular changes, endothelial receptor/endothelial cell contraction, the formation of endothelial gaps and the formation of bridges between cells (Putri, 2017). 
Molecular tissue-level therapy against LOX family members can inhibit pro-tumoral activity by minimizing side effects and resistance (Mayorca-Guiliani \& Erler, 2013). So that therapy for LOX is predicted to have a good success rate, thereby reducing the level of inflammation in the patient's body. The content of Acetylfuran and Furfural compounds in Tamarindus indica is predicted to have potential as an inhibitor of the LOX gene on different amino acid residues, namely three amino acid residues and four amino acid residues acid residues, respectively and producing binding energy. In addition, van der Waals forces, hydrogen and hydrophobic bonds were found, which gave the strength of the bonds formed.

\section{CONCLUSION}

In this study, we concluded that the acetylfuran and furfural compounds have a positive impact as inhibitor LOX. The interaction inhibits LOX and has an essential role in curving the inflammatory disease.

\section{REFERENCES}

Abdulkhaleq, L. A., Assi, M. A., Abdullah, R., ZamriSaad, M., Taufiq-Yap, Y. H. \& Hezmee, M. N. M. (2018). The Crucial Roles of Inflammatory Mediators in Inflammation: a Review. Veterinary World; 11; 627-635.

Adeola, A. A., Adeola, O. O. \& Dosumu, O. O. (2010). Comparative Analyses of Phytochemicals and Antimicrobial Properties of Extracts of Wild Tamarindus indica Pulps. African Journal of Microbiology Research; 4; 2769-2779.

Al-u'datt, D., Allen, B. G. \& Nattel, S. (2019). Role of the Lysyl Oxidase Enzyme Family in Cardiac Function and Disease. Cardiovascular Research; 115; 1820-1837.

Andriyono, R. I. (2019). Kaempferia galanga L. sebagai Anti-Inflamasi dan Analgetik. Jurnal Kesehatan; 10; 495-503.

Bare, Y., Kuki, A. D., Rophi, A. H. \& Candrakirana, G. (2019). Prediksi Asam Kuinat Sebagai AntiInflamasi Terhadap COX-2 Secara Virtual Virtual Prediction of Quinic Acid As Anti-Inflammation of COX-2. Biota: Jurnal Ilmu-Ilmu Hayati; 4; 124-129. https://doi.org/10.24002/biota.v4i3.2516

Bare, Y., Marhendra, A., Sasase, T. \& Fatchiyah, F. (2018). Differential Expression of IL-10 Gene and
Protein in Target Tissues of Rattus Norvegicus Strain Wistar Model Type 2 Diabetes Mellitus (T2DM). Acta Informatica Medica; 26; 87-92.

Bare, Y., Sari, D. R. T., Rachmad, Y. T., Krisnamurti, G. C. \& Elizabeth, A. (2019). In Silico Insight the Prediction of Chlorogenic Acid in Coffee through Cyclooxygenase-2 (COX2) Interaction. Biogenesis: Jurnal Ilmiah Biologi; 7; 100-105.

Bhadoriya, S. S., Ganeshpurkar, A., Narwaria, J., Rai, G. \& Jain, A. P. (2011). Tamarindus indica: Extent of Explored Potential. Pharmacognosy Review; 5; 73-81.

Bhadoriya, S. S. (2012). Anti-Inflammatory and Antinociceptive Activities of a Hydroethanolic Extract of Tamarindus indica Leaves. Scientia Pharmaceutica; 80; 685-700.

Borquaye, L. S., Doetse, M. S., Baah, S. O. \& Mensah, J. A. (2020). Anti-Inflammatory and Anti-Oxidant Activities of Ethanolic Extracts of Tamarindus indica L. (Fabaceae). Cogent Chemistry; 6; 1-11.

Chen, L., Deng, H., Cui, H., Fang, J., Zuo, Z., Deng, J., Li, Y., Wang, X. \& Zhao, L. (2018). Inflammatory Responses and Inflammation-Associated Diseases in Organs. Oncotarget; 9; 7204-7218.

Komakech, R., Kim, Y., Matsabisa, G. M. \& Kang, Y. (2019). Anti-Inflammatory and Analgesic Potential of Tamarindus indica Linn. (Fabaceae): a Narrative Review. Integrative Medicine Research; 8; 181-186.

Mayorca-Guiliani, A. \& Erler, J. T. (2013). The Potential for Targeting Extracellular LOX Proteins in Human Malignancy. OncoTargets and Therapy; 6; 1729-1735.

Mueller, M., Hobiger, S. \& Jungbauer, A. (2010). AntiInflammatory Activity of Extracts from Fruits, Herbs and Spices. Food Chemistry; 122; 987-996.

Putri, C. R. H. (2017). The Potency and Use of Tamarindus indica on Various Therapies. Jurnal Ilmiah Kedokteran Wijaya Kusuma; 3; 40-54.

Sari, D. R. T., Cairns, J. K., Safitri, A. \& Fatchiyah, F. (2019). Virtual Prediction of the Delphinidin-3-OGlucoside and Peonidin-3-O-glucoside as Antiinflammatory of TNF- $\alpha$ Signaling. Acta Informatica Medica; 27; 152-157.

Tiring, S. S. N. D., Bare, Y., Maulidi, A., S, M. \& Nugraha, F. A. D. (2019). Studi In Silico: Prediksi Potensi 6-shogaol dalam Zingiber Officinale sebagai Inhibitor JNK. Al-Kimia; 7; 147-153. 